\title{
Fen Bilgisi ve Sınıf Öğretmen Adaylarının Sürdürülebilir Çevreye Yönelik Tutumlarının İncelenmesi
}

\author{
HICRET ÇIMEN* \\ hcrtcmn@gmail.com \\ ORCID ID: 0000-0002-6671-9718
}

\author{
SEMRA BENZER** \\ sbenzer@gazi.edu.tr \\ ORCID ID: 0000-0002-8548-8994
}

Öz: Bu araştırma, fen bilgi ve sını öğretmenliği bölümlerinde okuyan öğretmen adaylarının sürdürülebilir çevreye yönelik tutumlarını incelemek amacıyla yapılmıştır. Araştırma 20172018 Ĕgitim- Öğretim döneminde Gazi Üniversitesi Eğitim Fakültesinde eğitim görmekte olan 342 fen bilgisi ve 324 sinı öğretmeni adayıyla yürütülmüştür. Araştırmada tarama modeli kullanılmıştır. Verilerin elde edilmesinde kişisel bilgi formu ve "Sürdürülebilir Çevre Tutum Ölçeği” kullanılmıştır. Araştırmadan elde edilen bulgulara göre öğretmen adaylarının genel anlamda sürdürülebilir çevreye yönelik tutumları yüksek düzeyde bulunmuştur. Ayrıca bölümler arasında fen bilgisi öğretmenliği bölümünde okuyan öğretmen adayları lehine, cinsiyete göre ise kız ögretmen adayları lehine anlaml fark vardır. Fen bilgisi öğretmen adaylarının sınıf düzeyleri arasında fark olup olmadığına bakıldiğında sınıf düzeyleri arasında fark bulunamamıştır. Sınıf öğretmenliği sınıf düzeylerine bakıldı̆̆ında 1-2 ve 2-4. sinıflar arasında anlamlı bir fark bulunmuştur. Ayrıca öğretmen adaylarının anne eğitim durumu, baba eğitim durumu, aile gelir durumları, mezun oldukları lise ve yaşadıkları yerleşim birimine göre de aralarında anlamlı fark bulunamamıştır.

Anahtar kelimeler: Başarı, Öğretmen adayları, Sürdürülebilir çevre, Tutum.

\section{Giriş}

Çevre kavramı denildiğinde insanların zihnine birçok tanım gelmektedir. Her kavramda biraz farklılıklar olsa da özünde hepsinin ifade ettiği çevre kavramı aynıdır. Türk Dil Kurumu çevreyi bir şeyin yakını, dolayı, etraf, perifer olarak tanımlamaktadır. Diğer bir tanımda ise çevre kişinin içinde bulunduğu toplumu oluşturan ortam olarak geçmektedir. Çevre, yeryüzündeki ilk canlı ile birlikte var olmuş bir ortamdır. ${ }^{1}$ Çevre, canlı ve cansız öğelerden oluşan bir bütündür. İnsan, hayvan, bakteri, hava, toprak, su gibi canlı ve cansız materyaller çevreyi oluşturan unsurlardandır. ${ }^{2}$

\footnotetext{
* Gazi Üniversitesi, Gazi Eğitim Bilimleri Enstitüsü, Yüksek Lisans Öğrencisi

** Doç.Dr., Gazi Üniversitesi, Gazi Eğitim Fakültesi, Fen Bilgisi Eğitimi

1 A. Seda Yücel ve F. İnci Morgil, "Yüksek Öğretimde Çevre Olgusunun Araştırılması”, Hacettepe Üniversitesi Eğitim Fakültesi Dergisi, 14 (1998): 84-91.

2 Osman Çimen, "Çevre Eğitiminde Tatlı Su Ekosistemleri Konusundaki Temel Kavramların Üniversite
} 
Canlıların yaşamlarını içinde geçirdikleri ve etkileşimde bulundukları ortama çevre denilmektedir. Canlılar ihtiyaçlarını çevreden karşılarlar ve çevreye hayati bağlarla bağlanırlar. ${ }^{3}$

Geçtiğimiz yüzyıl, bilim ve teknolojide büyük atılımların ve buluşların gerçekleştiği, insanlık tarihinin birçok değişim yaşadığı, sanayileşme, kentleşme, kalkınma ve bilgi yüzyılı olarak tarihe geçmiştir. ${ }^{4}$ Küreselleşen dünyada teknolojik şartlar hızla değişmektedir. Bu değişimlerle birlikte insanların yaşam düzeyi artarken, aynı zamanda artan nüfusla birlikte meydana gelen çevre sorunları da artmaktadır. Yani insan bilim ve teknolojideki gelişmelerin kaynağıyken aynı zamanda çevre sorunlarının da kaynağıdır. ${ }^{5}$

Çevre sorunları tarihin her döneminde, insanlığı etkilemiş olarak karşımıza çıksa da hiçbir zaman bugün olduğu gibi küresel ölçekte etkili olmamıştır. Gelişen teknoloji, sanayi faaliyetlerinin artması, hızla artan insan nüfusu 20. yüzyıldan itibaren çevre sorunlarını hızlı bir şekilde artırmıştır. ${ }^{6}$ Başlıca çevre sorunları arasında iklim değişikliği ve küresel ısınma, biyolojik çeşitlilik kaybı, erozyon ve çölleşme, ozon tabakası incelmesi ve kirlilik gelmektedir. Çevre kirlenmesinin başlıca sebepleri arasında, yerleşim merkezlerinde alt yapı eksikliği, sanayi tesislerinde geri kazanma tesislerinin bulunmayışı, bilinçsiz yapılan tarım, aşırı nüfus artışı ve uygun olmayan arazilerin yerleşime açılması bulunmaktadır. ${ }^{7}$

Son dönemlerde dünyada birçok yerde sel, kuraklık, şiddetli rüzgarlar, ölüme sebep olan yaz sıcakları gibi afetler çok fazla can ve mal kaybına neden olmaktadır. Bunlar, yıllardır bilim insanlarının dile getirdiği ancak daha çok kazanç hırsıyla göz ardı edilen acı gerçeklerle insanlığın yüzleşmesidir. Çevre konusundaki duyarsızlık böyle devam edecek olursa dünya daha birçok felaketle daha karşılaşacaktır. Bu felaketlerin temelinde insanların doğayı sömürmesi çıkarları uğruna doğayı acımasızca kullanması gelmektedir. Bu durumun sonucu olarak da hem bugün dünyada var olan canlıları hem de gelecekte var olacak olan canlıların yaşamlarını tehdit eden çevre sorunları insanlığa meydan okurcasına karşımızda durmaktadır. ${ }^{8}$

Ülkemizde ortaya çıkan çevre sorunlarının ana sebeplerinden biride bilgi edinme ve bilinçlenmede yaşanan eksiklerdir. Bilinçli olmayan toplum yaşadığı dünyayı kendinden sonra başkalarının da kullanacağını düşünmez. Oysa çevre bize bırakılan bir miras değil gelecek nesillere en iyi şekilde devredilmesi gereken bir emanettir. ${ }^{9}$

\footnotetext{
Öğrencileri Tarafından Algılanma Düzeyleri”, Yüksek Lisans Tezi, Gazi Üniversitesi, 2008, s.87.

3 Nihat Altınöz, "Fen Bilgisi Öğretmen Adaylarının Çevre Okuryazarlık Düzeyleri”, Yüksek Lisans Tezi, Sakarya Üniversitesi. 2010, s.83.

4 Emin Atasoy ve Hasan Ertürk, "İlköğretim Öğrencilerinin Çevresel Tutum ve Çevre Bilgisi Üzerine Bir Alan Araștırması”, Erzincan Eğitim Fakültesi Dergisi, 10/1 (2008): 105-122.

5 Seher Özcan, "Fen Bilgisi Öğretmen Adaylarının Çevre Sorunlarına İlişkin Görüşlerinin Farklı Teknikler Kullanılarak Tespit Edilmesi”, Yüksek Lisans Tezi, Abant İzzet Baysal Üniversitesi, 2010, s.163.

6 David L. Gadenne, Jessica Kennedy, ve Catherine McKeiver, "An empirical study of environmental awareness and practices in SMEs", Journal of Business Ethics, 84 (2009): 45-63.

7 Yücel ve Morgil, s. 87.

8 Sinan Erten, “Çevre Eğitimi ve Çevre Bilinci Nedir, Çevre Eğitimi Nasıl Olmalıdır?”, Çevre ve İnsan Dergisi, 65/66 (2004): 1-13.

9 Tuğba Akbaş, “Fen Bilgisi Öğretmen Adaylarında Çevre Olgusunun Araştırılması”, Yüksek Lisans Tezi, Atatürk
} 
Ekolojik olaylar iyi veya kötü yönde olabilirler. Önemli olan doğanın kendini yenileyebilecek seviyede kalması ve yok olmamasıdır. ${ }^{10}$ Doğanın bu seviyede kalması ise insanların üzerine düşen bir görevdir. 1982 Anayasası’nın 56. Maddesinde "Sağlıklı, dengeli bir çevrede yaşamak her canlının hakkıdır. Yaşanılan çevreyi korumak, geliştirmek ve kirlenmesini önlemek başta vatandaşların ve devletin ödevidir." denilmektedir. 1983 tarih 2872 sayılı Çevre Kanunu'nda "Başta idare olmak üzere, sivil toplum kuruluşları, meslek odaları, birlikler kirliliğin önlenmesinde, çevrenin korunmasında görevli ve belirlenen ilkelere uymakla yükümlüdürler." ifadesi yer almaktadır. Ancak hak ve görevlerin işlerlik kazanabilmesi çevre bilincinin oluşturulmasıyla mümkündür. Bunun yolu da tüm toplumu içine alan bir eğitim programı oluşturmaktır. ${ }^{11}$

Bu eğitime ise çok küçük yaşlardan başlanmalıdır ki ağaç yaşken eğilir mantığı ile küçük yaşlardan itibaren çevre bilinci yüksek, çevreye karşı duyarlı bireyler yetiştirilsin. Ancak bu eğitim sadece okullardan beklenmemelidir. Çocuklar zamanlarının çoğunu aileleriyle geçirdiği için çevre eğitimi ailede başlamalıdır. Anne babalar örnek olacak davranışlarıyla da bu eğitime destek vermelidir.

Çevre eğitimi bireyler açısından aktif niteliğe sahip olmalıdır. Sadece bilgilendirici olmayıp karar alma süreçlerine de katmalıdır. Çevre sorunlarının oluşumu ve önlenmesinde hem bireylerin hem devletin rolü vardır. Bu oluşumlara engel olmakta yine bireylerin ve devletin sorumluluğudur. Bu sorumlulukların yerine getirilmesi içinde eğitim gereklidir. ${ }^{12}$

İnsanın çevreye verdiği zarar yine kendine dönecektir. Bilinçsizce yapılan davranışlar basit görülüp önemsenmeyen zararlar bu kadarından bir şey olmaz düşünceleri hem insanın kendi yaşam kaynaklarını hem de kendinden sonra gelecek olan neslin yaşam kaynaklarını tüketmektedir. İşte burada sürdürülebilir kalkınma kavramı da ortaya çıkmaktadır.

Sürdürülebilir kalkınma kavramı ilk olarak Dünya Çevre ve Kalkınma Komisyonu'nun 1987 yılında hazırladığı Brundtland Raporu’nda, "Bugünün ihtiyaçlarını gelecek kuşakların ihtiyaçlarını karşılanmasına engel olmadan karşılayan kalkınma” olarak ifade edilmiştir. Çevre eğitimi çevre sorunlarını ortadan kaldırmanın ve sürdürülebilir kalkınmayı gerçekleştirmenin temelidir. ${ }^{13}$

Günlük yaşantımızdaki kaynak kullanımının yeterlik, etkililik, doğaya uygunlu ver aktif katılım ilkelerine göre hayata geçmesi ile sürdürülebilirlik somutlaşmaktadır. Bu yüzden bu ilkeleri ne kadar gözetirsek sürdürülebilirliği o ölçüde yakalarız. ${ }^{14}$

Alpak, fen bilgisi öğretmen adaylarının sürdürülebilir çevreye yönelik tutumlarını

Üniversitesi, 2007, s.86.

10 Carolyn Strong, "The impact of environmental education on children's knowledge and awareness of environmental concerns", Marketing Intelligence \& Planning, 16 (1998): 349-355.

11 Gadenne, Kennedy ve McKeiver, An empirical, s.50.

12 Akbaş, Fen Bilgisi, s.25.

13 Gaye Teksöz, Elvan Şahin ve Hamide Ertepınar, “Çevre Okuryazarlığı, Öğretmen Adayları ve Sürdürülebilir Bir Gelecek”, Hacettepe Üniversitesi Ĕ̆itim Fakültesi Dergisi, 39 (2010): 307-320.

14 Oğuz Özdemir, Ekolojik Okuryazarlık ve Çevre Eğitimi. Ankara, Pegem Akademi, 2016. 
incelemek için yaptığ çalışmanın sonucunda sürdürülebilir çevreye yönelik tutumların; sınıf düzeyi, cinsiyet, Çevre Bilimi dersi alma, herhangi bir çevre kuruluşuna üye olma gibi değişkenlerine göre anlamlı farklılık olduğu sonucuna ulaşmıştır. ${ }^{15}$ Kahraman, eğitim Fakültesi öğrencilerinin çevresel sorunlara yönelik normlarının zamansal ve uzamsal boyutta karşılaştırılması üzerine araştırma yapmıştır. ${ }^{16}$ Soysal, sosyal bilgiler fen bilgisi ve sınıf öğretmenliği bölümlerinin son sınıfında eğitim gören öğretmen adaylarıyla yaptığ çalışmada öğretmen adaylarının sürdürülebilir çevreye yönelik tutumlarına bakmıştır. ${ }^{17}$ Akyol, ilköğretim fen bilgisi, sosyal bilgiler ve sınıf öğretmenliği programlarında eğitim gören öğretmen adaylarının çevreye yönelik tutumlarını ve çevre bilgi düzeylerini belirlenmeye çalışmıştır. ${ }^{18}$ Karataş, yaptığı çalışmasında çevre eğitiminin çevre bilincinin kazandırılmasındaki rolünü konu olarak ele almıştır. ${ }^{19}$ Bilim, sürdürülebilir çevre açısından eğitim fakültesinde okuyan öğrencilerin çevre okuryazarlık düzeylerini belirlemek için yaptığ çalışma sonucunda eğitim fakültesi öğrencilerinin çevre okuryazarlık düzeylerinin orta düzeyde olduğunu, çevresel bilgi çevresel davranış ve çevresel algı düzeylerinin orta düzeyde olduğu kısmen yüksek düzeyde çevresel tutuma sahip oldukları sonucuna ulaşmıştır. ${ }^{20}$ Uğulu ve Erkol, biyoloji öğretmenliği bölümünde okuyan adayların çevreye karşı tutumlarını belirlemek ve bu tutumları çeşitli değişkenlere göre karşılaştırmak amacıyla yaptıkları çalışmada biyoloji öğretmeni adaylarının çevreye karşı tutumlarının sınıf ve yaş düzeyi arttıkça arttığını ancak bu değişkenlerin öğretmen adayları arasında anlamlı bir fark oluşturmadığı görülmüştür. ${ }^{21}$

Akgül ve Akgül, fen bilgisi öğretmenliği bölümünde okuyan öğretmen adaylarının tarım konusunda fikirlerini içeren özel durumlarının araştırıldığı bir çalışma yapmışlardır. ${ }^{22}$ Altınöz, Fen bilgisi öğretmenliği bölümünde öğrenim gören öğretmen adaylarının çevre okuryazarlık düzeylerini belirlemek için bir çalışma yapmıştır. ${ }^{23}$ Özcan, Fen Bilgisi alanında okuyan öğretmen adaylarının çevre sorunları hakkındaki görüşlerinin farklı yöntemler kullanılarak tespit edilmesi ile ilgili olarak bir araştırma yapmıştır. ${ }^{24}$ Akıllı ve Yurtcan, Fen Bilgisi öğretmen adaylarının çevreye yöne-

15 Gizem Alpak, “Fen Bilgisi Öğretmen Adaylarının Çevreye Yönelik Etik Yaklaşımları ile Sürdürülebilir Çevreye Yönelik Tutumlarının İncelenmesi”, Yüksek Lisans Tezi, Adnan Menderes Üniversitesi, 2016, s.155.

16 Nazan Kahraman, "Eğitim Fakültesi Öğrencilerinin Çevre Sorunlarına Yönelik Normlarının Karşılaştırılması”, Yüksek Lisans Tezi, Adnan Menderes Üniversitesi, 2016, s.179.

17 Kübra Soysal, “İlköğretim Öğretmen Adaylarının Sürdürülebilir Çevre Eğitimine Yönelik Tutumları”, Yüksek Lisans Tezi, Ondokuz Mayıs Üniversitesi, 2016, s.76.

18 Buket Akyol, "İlköğretim Öğretmen Adaylarının Çevresel Tutum ve Çevre Bilgi Düzeyleri Üzerine Bir Çalışma”, Yüksek Lisans Tezi, Niğde Üniversitesi, 2014, s.94.

19 Abdullah Karataş, (2013). "Çevre Bilincinin Geliştirilmesinde Çevre Eğitiminin Rolü ve Niğde Üniversitesi Eğitim Fakültesi Örneği”, Doktora Tezi, Ankara Üniversitesi, 2013, s.279.

20 İrfan Bilim, "Sürdürülebilir Çevre Açısından Eğitim Fakültesi Öğrencilerinin Çevre Okuryazarlık Düzeylerinin Belirlenmesi”. Yüksek Lisans Tezi, Afyon Kocatepe Üniversitesi, 2012, s.143.

21 İlker Uğulu ve Sevilay Erkol, “Biyoloji Öğretmen Adaylarının Çevreye Yönelik Tutumları ve Çeşitli Değişkenler Açısından İncelenmesi”, Balıkesir Üniversitesi Yeni Dünya Bilimleri Akademisi e-Dergisi, 8/1 (2013): 78-89.

22 Hasan Celal Akgül ve Esra Macaroğlu Akgül, "Fen Eğitiminde Yeni Bir Kavram: Tarımsal Farkındalık İlköğretim Öğretmen Adaylarının Genel, Fen Bilgisi Öğretmen Adaylarının Özel Durumu”, Sakarya Üniversitesi Ĕ̈itim Dergisi, 1/1 (2010): 15-25.

23 Nihat Altınöz, "Fen Bilgisi Öğretmen Adaylarının Çevre Okuryazarlık Düzeyleri”, Yüksek Lisans Tezi, Sakarya Üniversitesi, 2010, s.83.

24 Özcan, "Fen Bilgisi Öğretmen Adaylarının “, s.163. 
lik tutumlarını bazı değişkenler açısından incelemek için bir çalışma yapmışlardır. ${ }^{25}$ Akbaş, Fen bilgisi öğretmen adaylarının birinci sınıfta sahip oldukları çevre bilgileri ile dört yılın sonunda sahip oldukları çevre tutum ve bilgilerini karşılaştırmış ve dördüncü sınıf öğrencilerinin birinci sınıf öğrencilerine göre çevre duyarlılıklarının daha fazla olduğu gözlenmiştir. ${ }^{26}$ Tuncer ve ark., Türkiyedeki üniversite öğrencilerinin sürdürülebilir kalkınma ile ilgili görüşlerinin alınması ve değerlendirilmesi amacıyla bir çalışma yapmıştır. ${ }^{27}$ Sonuçlar incelendiğinde öğretmen adayları, sürdürülebilir kalkınmayı çevre sorunlarına çözüm yollarından biri olarak gördükleri ve çevresel problemlerin çözümünde kişisel sorumluluk alma eğiliminde olduklarını sonucuna ulaşılmıştır.

\section{Araştırmanın Amaç ve Önemi}

Çevre eğitiminde amaç çevreye ve çevre sorunlarına duyarlı vatandaş yetiştirmektir. Çevreye duyarlı vatandaş yetiştirilebilmesi içinde çevre eğitiminin içinde sürdürülebilir kalkınma eğitimi temel amaç olmalıdır. Çünkü sadece çevreyi sevmek ve canlı cansız unsurların farkında olmak sürdürülebilirlik için yeterli değildir. İnsanların kaliteli bir yaşam sürmesi doğayla uyumlu ve barışık yaşam tarzı benimsemeleriyle mümkündür. Sürdürülebilir kalkınma eğitimi bireylerin doğal kaynaklardan yararlanma ve sürdürülebilirliği yaşam biçimi haline getirmesi hakkında bilgi sahibi olma sürecidir. ${ }^{28}$

Çevreye karşı duyarlılığı yüksek olan, yeterli bilgiye sahip, teorik ve uygulamalı çevre çalışmalarını başarıyla yürütebilecek yeterlilikte öğretmenlerin yetiştirilmesi çevre eğitiminin amaçladığı hedeflere ulaşmak açısından büyük önem taşır. Bu yüzden çevreye duyarlı ve çevre hakkında yeterli bilgiye sahip bireylerin yetiştirilmesinde ve bireylere istendik yönde davranışla kazandırılmasında öğretmenlere büyük sorumluluklar düşmektedir. ${ }^{29}$ Teorik ve uygulamalı çevre eğitimiyle çevre bilinci artırılan bugünün çocuklarının çevreleriyle ilgili edindikleri bilgiler sayesinde ileriki yaşamlarında çevrelerini korumak için ellerinden gelen gayreti göstereceklerdir. Bugünün çocuklarına bu bilinci kazandıracak olan öğretmenlerin bu konuda ne kadar donanımlı oldukları büyük önem taşımaktadır. Bu bağlamda da öğretmenlerin yetiştirildiği eğitim fakültelerine büyük sorumluluklar düşmektedir. Öğretmen adaylarına verilecek olan çevre eğitiminin bu bağlamda amaca hizmet etmesi ve öğretmen adaylarına gerekli bilgi ve donanımı sağlaması gerekmektedir. ${ }^{30}$

25 Mustafa Akıllı ve Mustafa T. Yurtcan, "İlköğretim Fen Bilgisi Öğretmeni Adaylarının Çevreye Karşı Tutumlarının Farklı Değişkenler Açısından İncelenmesi (Kazım Karabekir Eğitim Fakültesi Örneği)”, Erzincan Ĕ̆itim Fakültesi Dergisi, 11/2 (2009): 119-131.

26 Akbaş, Fen Bilgisi, s.30.

27 Gaye Tuncer, Ceren Tekkaya ve Semra Sungur, "Öğretmen Adaylarının Sürdürülebilir Kalkınma ile ilgili inançları Cinsiyet ve Çevre Dersine Katılımın Etkisi”, Hacettepe Üniversitesi Eğitim Fakültesi Dergisi, 31 (2006): 179-187.

28 Ayşe Çelikbaş, "Sürdürülebilirliği Temel Alan Çevre Eğitiminin Ortaokul Öğrencilerinin Çevresel Davranışlarına ve Sürdürülebilir Çevre Tutumlarına Etkisi”, Yüksek Lisans Tezi, Mersin Üniversitesi, 2016, s.159. 29 Mustafa Kahyaoğlu ve Nurettin Özgen, "Öğretmen Adaylarının Çevre Sorunlarına Yönelik Tutumlarının Çeşitli Değişkenler Açısından İncelenmesi”, Kuramsal Eğitimbilim Dergisi, 5/2 (2012): 171-185.

30 Karataş, Çevre Bilincinin, s.125. 
Okulda kazandırılmaya çalışılan çevre eğitiminde öğretmenlerin çok büyük öneme sahip olduğu bilinmektedir, öğretmenlerin çevre duyarlılığı konusunda bilinç seviyelerinin belirlenmesi, gelecekteki nesillerinde ne kadar bilinçli ya da sorumluluk sahibi bireyler olacağını belirlenmesi açısından bilgi vermektedir. Çözümler için ihtiyaçların neler olduğunun somut olarak belirlenmesi oldukça önemlidir. ${ }^{31}$

$\mathrm{Bu}$ çalışmada amaç gelecek nesilleri yetiştirecek olan öğretmenlerden fen bilgisi ve sınıf öğretmenliği bölümlerinde okuyan öğretmen adaylarının sürdürülebilir çevreye yönelik tutumlarının ne düzeyde olduğu araştırılmaktadır.

\section{Problem Cümlesi}

Fen bilgisi ve sınıf öğretmeni adaylarının sürdürülebilir çevreye yönelik tutumları arasında anlamlı bir fark var mıdır?

\section{Alt Problemler}

- $\quad$ Fen bilgisi ve sınıf öğretmenliği 1, 2, 3 ve 4. Sınıfta okuyan öğretmen adaylarının sürdürülebilir çevreye yönelik tutumları arasında anlamlı bir fark var mıdır?

- $\quad$ Fen bilgisi öğretmenliği bölümünde okuyan öğretmen adaylarının sürdürülebilir çevreye yönelik tutumları sınıf düzeylerine göre aralarında anlamlı bir farklilık var midir?

- S Sınıf öğretmenliği bölümünde okuyan öğretmen adaylarının sürdürülebilir çevreye yönelik tutumları sınıf düzeylerine göre aralarında anlamlı bir farklılık var midir?

- Öğretmen adaylarının okudukları bölüm türüne, cinsiyet durumuna, anne eğitim düzeylerine, baba eğitim düzeylerine aile gelir durumlarına, mezun oldukları lise türüne ve yaşadıkları yerleşim yerine göre sürdürülebilir çevreye yönelik tutumları bakımından aralarında anlamlı bir fark var mıdır?

\section{Yo̊ntem}

\section{Araştırma Modeli}

Bu araştırma da fen bilgisi ve sınıf öğretmeni adaylarının sürdürülebilir çevreye yönelik tutumlarını belirlemek için nicel araştırma yöntemlerinden biri olan tarama modeli kullanılmıştır. Bu model bir grubun belirli özelliklerini saptamak için veri toplamayı amaçlayan bir çalışmadır. ${ }^{32} \mathrm{Bu}$ amaçla uygulanacak ölçekler gerekli izinler alınarak, gönüllülük esasıyla öğretmen adaylarına uygulanmıştır.

\section{Araştırma Grubu}

Bu araştırma, 2017-2018 yılında Gazi Üniversitesi Eğitim Fakültesi’nin Fen Bilgisi ve

31 Yasemin Aksu, "Fen ve Teknoloji ile Sınıf Öğretmenlerinin Çevre Sorunlarına Yönelik Tutumlarının Belirlenmesi (Burdur İli Örneği)”, Yüksek Lisans Tezi, Süleyman Demirel Üniversitesi, 2009, s.94. 
Sınıf Öğretmenliği bölümlerinde eğitim görmekte olan öğretmen adayları oluşturmaktadır.

\section{Veri Toplama Araçları}

\section{Sürdürülebilir Çevre Tutum Ölçeği}

Yıldız, tarafından geliştirilen ölçek 27 maddeden oluşmuş 5’li likert tipi bir ölçektir. ${ }^{33}$ Ölçeğin cronbach alpha değeri .89 bulunmuş ve güvenirliğin yüksek olduğu görülmüştür. Ölçeğin puanlanırken cevaplar olumsuzdan olumluya doğru sırayla; 1,2 , 3, 4, 5 puan şeklinde değerlendirilecektir. Olumsuz soru köküne sahip maddelerin değerlendirilmesinde ise puanlar olumsuzdan olumluya doğru; 5, 4, 3, 2, 1 şeklinde değerlendirilmiştir.

\section{Verilerin Çözümlenmesi ve Yorumlanması}

Gerekli izinler alındıktan sonra Gazi Üniversitesi Eğitim Fakültesinde öğrenimlerine devam eden fen bilgisi ve sınıf öğretmeni adaylarına "Sürdürülebilir Çevre Tutum Ölçeği” uygulanmıştır. Anketlerden elde edilen nicel veriler SPSS version 22 programı ile analiz edilmiştir.

\section{Bulgular}

Toplam 666 öğretmen adayıyla çalışma yapılmıştır. Öğretmen adaylarından 342 (\%51,6)'sinin fen bilgisi öğretmenliği bölümünde, 324 (\%48,6)'ünün sınıf öğretmenliği bölümünde okuduğu görülmektedir. 342 fen bilgisi öğretmen adayından 86's1 $(\% 25,1)$ birinci sınıf, 91’i $(\% 26,6)$ ikinci sınıf, 80’i $(\% 24,9)$ üçüncü sınıf, 85’i $(\% 24,9)$ dördüncü sınıf öğrencisidir. Sınıf öğretmenliği bölümünde okuyan öğretmen adaylarına bakıldığında ise 80’i (\%24,7) birinci sınıf, 82'si (\%25,3) ikinci sınıf, 82'si (\%25,3) üçüncü sınıf, 80’i $(\% 24,7)$ dördüncü sınıftır.

Fen bilgisi ve sınıf öğretmenliği 1. sınıfta okuyan öğretmen adaylarının sürdürülebilir çevreye yönelik tutumları arasında $(\mathrm{p}=, 238)$ anlamlı bir fark olmadı̆̆ rağmen fen bilgisi öğretmen adaylarının tutum ortalamalarının daha yüksek olduğu söylenebilir. 2.sınıfta okuyan öğretmen adaylarının sürdürülebilir çevreye yönelik tutumları arasında $(\mathrm{p}=, 998)$ anlamlı bir fark olmadığı buna rağmen sınıf öğretmenliği öğretmen adaylarının tutum puanlarının ortalamalarının daha yüksek olduğunu söyleyebilir. Fen bilgisi ve sınıf öğretmenliğinde. 3. sınıfta okuyan öğretmen adaylarının sürdürülebilir çevreye yönelik tutumları arasında anlamlı $(\mathrm{p}=, 238)$ bir fark olmadığ yüksek olduğunu söylenebilir.4. sınıfta okuyan öğretmen adaylarının sürdürülebilir çevreye yönelik tutum puanlarının aralarında anlamlı $(\mathrm{p}=, 031)$ fen bilgisi öğretmen adaylarının lehine anlamlı fark olduğu sonucuna varılmıştır (Tablo1).

33 Şahika Yıldız, "Öğretmenlerin, Öğretmen Adaylarının Ve Öğrencilerin Sürdürülebilir Çevre İle İlgili Kavramsal Anlamaları ve Tutumları”, Yüksek Lisans Tezi, Dokuz Eylül Üniversitesi, 2011, s.443. 
Tablo 1. Fen Bilgisi ve Sını Öğretmeni Adaylarının Sürdürülebilir Çevreye Yönelik Tutumlarının Karşılaştırılması

\begin{tabular}{|c|c|c|c|c|c|c|}
\hline Grup & $N$ & $X \rrbracket$ & $S$ & $S d$ & $T$ & $P$ \\
\hline \multicolumn{7}{|l|}{ 1. Sinif } \\
\hline Fen Bilgisi & 86 & 106,80 & 10,592 & \multirow{2}{*}{164} & \multirow{2}{*}{1,044} & \multirow{2}{*}{, 298} \\
\hline Sinıf Öğrt & 80 & 105,13 & 10,079 & & & \\
\hline \multicolumn{7}{|l|}{ 2. Sinif } \\
\hline Fen Bilgisi & 91 & 108,81 & 11,779 & \multirow{2}{*}{171} & \multirow{2}{*}{,- 022} & \multirow{2}{*}{,998 } \\
\hline Sinıf Öğrt & 82 & 108,82 & 9,746 & & & \\
\hline \multicolumn{7}{|l|}{ 3. Sinif } \\
\hline Fen Bilgisi & 80 & 109,73 & 9,945 & \multirow{2}{*}{160} & \multirow{2}{*}{1,183} & \multirow{2}{*}{, 238} \\
\hline Sınıf Öğrt & 82 & 107,76 & 11,180 & & & \\
\hline \multicolumn{7}{|l|}{ 4. Sinıf } \\
\hline Fen Bilgisi & 85 & 108,36 & 11,391 & \multirow{2}{*}{163} & \multirow{2}{*}{2,180} & \multirow{2}{*}{, 031} \\
\hline Sinıf Öğrt & 80 & 104,76 & 9,707 & & & \\
\hline
\end{tabular}

Tablo 2'ye göre fen bilgisi öğretmen adaylarının sınıf düzeylerine göre sürdürülebilir çevreye yönelik tutum düzeyleri bakımından aralarında anlamlı bir farklılık olmadığı sonucuna ulaşılmıştır. Sınıf öğretmeni adaylarının sınıf düzeylerine göre aralarında anlamlı bir farklılık olduğu tespit edilmiştir. Hangi sınıf düzeyleri arasında fark olduğunu anlamak için LSD testi yapılmıştır. İlişkisiz üç ya da daha çok örneklem ortalaması arasındaki farkın anlamlılığını test etmek amacıyla yapılan ANOVA'da grupların evren ortalamaları için en az iki grup arasında anlamlı bir fark bulunmuşsa bu farkın ya da farkların hangi gruplar arasında olduğunun bulunması için uygun bir çoklu karşılaştırma testinin kullanılması gerekmektedir. Grup varyanslarının eşit olduğu durumlarda ortalama puanların çoklu karşılaştırmasında sıklıkla kullanılan testler arasinda Scheffe, Tukey HSD, Bonferronni ve Fischer'in LSD testi sayılabilir. ${ }^{34}$

Tablo 2. Fen Bilgisi ve SınıfÖğretmeni Adaylarının Sınıf Düzeylerine Göre Sürdürülebilir Çevreye Yönelik Tutumlarının Karşılaştırılması

\begin{tabular}{|c|c|c|c|c|}
\hline Eğitim düzeyi & $N$ & $X \bigotimes$ & $S$ & $p$ \\
\hline \multicolumn{5}{|c|}{ Fen Bilgisi Öğretmenliğ } \\
\hline 1. Sinif & 86 & 106,80 & 10,592 & \multirow{4}{*}{,375 } \\
\hline 2. Sinif & 91 & 108,81 & 11,779 & \\
\hline 3. Sinif & 80 & 109,73 & 9,945 & \\
\hline 4. Sinif & 85 & 108,36 & 11,391 & \\
\hline \multicolumn{5}{|c|}{ SinıfÖğretmenliği } \\
\hline
\end{tabular}

34 Büyüköztürk, K1lıç Çakmak, Akgün, Karadeniz ve Demirel, Bilimsel Araştırma, s.356. 


\begin{tabular}{|c|c|c|c|c|}
\hline 1. Sinif & 80 & 105,13 & 10,079 & \multirow{4}{*}{,028 } \\
\hline 2. Sinif & 82 & 108,82 & 9,746 & \\
\hline 3. Sinif & 82 & 107,76 & 11,180 & \\
\hline 4. Sinif & 80 & 104,76 & 9,707 & \\
\hline
\end{tabular}

Sınıf öğretmenliği bölümünde okuyan öğretmen adaylarının sınıf düzeylerine göre aralarında bir farklılık olup olmadığına bakılmış ve tüm sınıf düzeyleri birbiriyle karşılaştırılmıştır. Sınıf öğretmenliği bölümlerinde okuyan öğretmen adaylarının sınıf düzeylerine göre sürdürülebilir çevreye yönelik tutum düzeyleri bakımından 1 . sinıflar ile 2. sınıflar arasında ve 2. sınıf ve 4. sınıf öğrencileri arasında anlamlı bir fark olduğu $(\mathrm{p}<, 05)$ diğer sınıf düzeylerinin aralarında anlamlı bir farklılık olmadığ sonucuna ulaşılmıştır (Tablo 2).

Tablo 3. Sınıf Öğretmeni Adaylarının Sınıf Düzeyleri Arasında Sürdürülebilir Çevreye Yönelik Tutumlarının Karşılaştırılması

\begin{tabular}{|l|c|c|c|c|}
\hline & 1.sinıf & 2.sinif & 3. sinıf & 4. sinıf \\
\hline 1. sinif & - &, 022 &, 102 &, 822 \\
\hline 2. sinıf &, 022 & - &, 506 &, 012 \\
\hline 3. sinif &, 102 &, 506 & - &, 063 \\
\hline 4.sinif &, 822 &, 012 &, 063 & - \\
\hline
\end{tabular}

Tablo 4. Öğretmen Adaylarının Sürdürülebilir Çevreye Yönelik Tutumlarının Karşılaştırılması

\begin{tabular}{|l|c|c|c|c|c|c|}
\hline Grup & $N$ & $X$ & $S$ & $S d$ & $T$ & $P$ \\
\cline { 1 - 4 } Fen bilgisi & 342 & 108,41 & 10,980 & \multirow{2}{*}{664} & 2,147 & \multirow{2}{*}{, 032} \\
\hline Simıf öğrt & 324 & 106,64 & 10,297 & & & \\
\hline
\end{tabular}

Fen bilgisi ve sınıf öğretmenliği öğretmen adaylarının sürdürülebilir çevre hakkındaki tutumları karşılaştırılmıştır. Fen bilgisi ile sınıf öğretmenliği öğretmen adaylarının öğrencileri arasında fen bilgisi öğretmenliği lehine anlamlı bir farklılık olduğu sonucuna ulaşılmıştır $(\mathrm{p}<, 05$, Tablo 4$)$.

Tablo 5. Öğretmen Adaylarının Cinsiyet Durumuna Göre Sürdürülebilir Çevreye Yönelik Tutumlarının Karşılaştırılması

\begin{tabular}{|l|c|c|r|r|r|r|}
\hline Grup & $N$ & $X$ & $S$ & $S d$ & $T$ & $P$ \\
\cline { 1 - 5 } Kız & 592 & 107,85 & 10,487 & \multirow{2}{*}{664} & 2,076 & \multirow{2}{*}{, 038} \\
\cline { 1 - 4 } Erkek & 74 & 105,12 & 11,934 & & & \\
\hline
\end{tabular}

Öğretmen adaylarının cinsiyet durumlarına göre aralarında anlamlı bir farklılık olup olmadığına bakılmış. 592 kız öğretmen adayı ile 74 erkek öğretmen adayı karşılaştırılmıştır. Kız öğretmen adayları ile erkek öğretmen adayları arasında anlamlı bir farklılık olmadığı sonucuna ulaşılmıştır ( $\mathrm{p}>, 05$, Tablo 5). 
Tablo 6. Anne ve Baba Eğitim Durumunun Öğretmen Adayların Sürdürülebilir Çevreye Yönelik Tutumlarının Karşılaştırılması

\begin{tabular}{|c|c|c|c|c|}
\hline Eğitim Düzeyi & $N$ & $\mathrm{X} \nabla$ & $S$ & $p$ \\
\hline \multicolumn{5}{|c|}{ Anne Eğitim Durumu } \\
\hline Okuryazar değil & 18 & 108,61 & 7,823 & \multirow{6}{*}{ 179, } \\
\hline Okuryazar & 21 & 104,86 & 10,734 & \\
\hline İlkokul & 291 & 108,07 & 10,567 & \\
\hline Ortaokul & 115 & 108,73 & 10,461 & \\
\hline Lise & 165 & 106,93 & 10,736 & \\
\hline Yüksekokul-fakülte & 56 & 104,89 & 11,990 & \\
\hline \multicolumn{5}{|c|}{ Baba Eğitim Durumu } \\
\hline Okuryazar değil & 4 & 98,50 & 13,178 & \multirow{6}{*}{100} \\
\hline Okuryazar & 14 & 104,29 & 4,393 & \\
\hline İlkokul & 162 & 108,72 & 9,823 & \\
\hline Ortaokul & 143 & 108,58 & 10,297 & \\
\hline Lise & 190 & 106,66 & 11,656 & \\
\hline Yüksekokul-fakülte & 153 & 106,97 & 10,818 & \\
\hline
\end{tabular}

Öğretmen adaylarının annelerinin eğitim durumlarına göre sürdürülebilir çevreye yönelik tutumları arasında anlamlı bir farklılık olup olmadığını anlamak için sonuçlar tek yönlü ANOVA ile analiz edilmiştir (Tablo 6). Sonuç olarak öğretmen adaylarının annelerinin mezuniyet durumunun, öğretmen adaylarının sürdürülebilir çevreye yönelik tutumlarına etkisi olmadı̆̆ı anlaşılmıştır. Öğretmen adaylarının babalarının eğitim durumlarına göre sürdürülebilir çevreye yönelik tutumları arasında anlamlı bir farklılık olup olmadığını anlamak için sonuçlar tek yönlü ANOVA ile analiz edilmiştir (Tablo 6). Sonuç olarak öğretmen adaylarının babalarının mezuniyet durumunun, öğretmen adaylarının sürdürülebilir çevreye yönelik tutumlarına etkisi olmadığı anlaşılmıştır.

Tablo 7. Aile Gelir Durumu, Mezun Olunan Lise Türü ve Yaşanılan Yerleşim Yerinin Öğretmen Adayların Sürdürülebilir Çevreye Yönelik Tutumlarının Karşılaştırılması

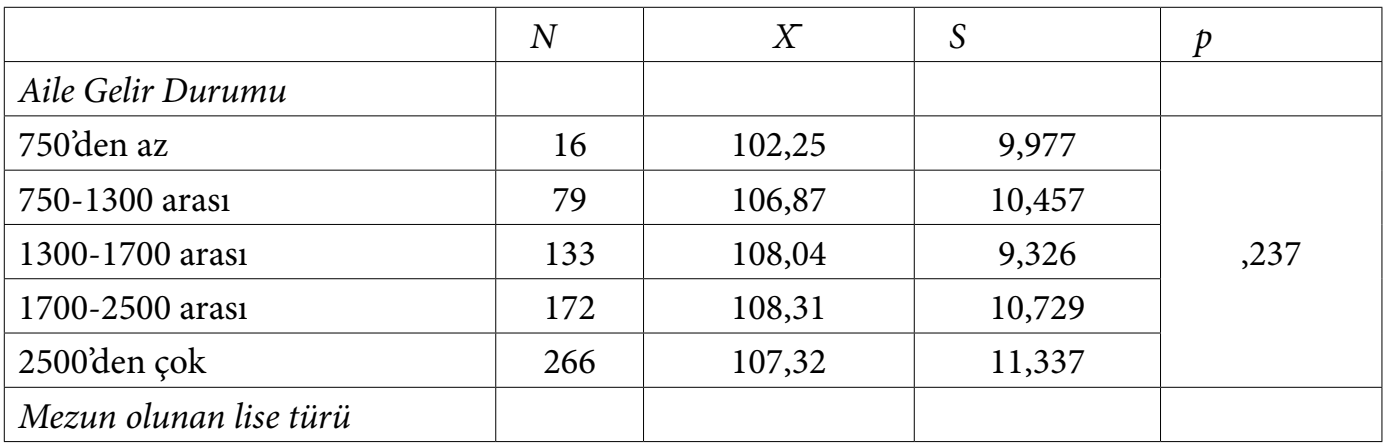




\begin{tabular}{|c|c|c|c|c|}
\hline Düz lise & 116 & 107,41 & 11,351 & \multirow{3}{*}{139} \\
\hline Anadolu lisesi & 509 & 107,32 & 10,506 & \\
\hline Meslek lisesi & 41 & 110,76 & 10,663 & \\
\hline \multicolumn{5}{|c|}{ Yaşanılan Yerleşim Yeri } \\
\hline Köy & 73 & 108,55 & 11,561 & \multirow{4}{*}{, 568} \\
\hline Kasaba & 63 & 107,02 & 9,738 & \\
\hline Şehir & 254 & 106,94 & 10,208 & \\
\hline Büyükşsehir & 276 & 107,96 & 11,084 & \\
\hline
\end{tabular}

Öğretmen adaylarının ailelerinin gelir durumları, mezun olunan lise türü ve yaşanılan yerleşim yerine göre sürdürülebilir çevreye yönelik tutumları arasında anlamlı bir farklılık olup olmadığını anlamak için sonuçlar tek yönlü ANOVA ile analiz edilmiştir (Tablo 7). Sonuç olarak öğretmen adaylarının ailelerinin gelir durumları, mezun olunan lise türü ve yaşanılan yerleşim yerine göre öğretmen adaylarının sürdürülebilir çevreye yönelik tutumlarına etkisi olmadığı anlaşılmıştır.

\section{Tartışma ve Sonuç}

Söz konusu araştırmada; fen bilgisi ve sınıf öğretmenliği bölümlerinde okuyan öğretmen adaylarının sürdürülebilir çevreye yönelik tutumları yüksek düzeyde bulunmuştur. İki bölüm arasında istatistiksel olarak fark var mı diye bakıldığında fen bilgisi öğretmenliği lehine anlamlı sonuç çıkmıştır. Bu farkın fen bilgisi öğretmenliği bölüm derslerinin (kimyada özel konular, çevre eğitimi, biyolojide özel konular, genel biyoloji 1) konuları arasında çevre ile ilgili bilgilerin olması düşünülmektedir. Karataş, yaptığı çalışmada Fen Bilgisi öğretmen adaylarının çevre bilinci düzeyinin Sosyal Bilgiler ve Sınıf öğretmen adaylarına göre daha yüksek olduğu sonucuna ulaşmıştır. ${ }^{35}$ Ancak Polat, öğretmen adaylarının çevre sorunlarına yönelik tutumları ile öğrenim gördükleri lisans programı arasında farklılık olmadığı sonucuna ulaşmıştır. ${ }^{36} \mathrm{Ak}$, yaptığı öğretmen adaylarının çevreye yönelik bilinçlerinin bazı demografik değişkenler açısından incelenmesi üzerine yaptığı çalışmada öğretmen adaylarının çevre bilinç düzeylerinin fen bilgisi öğretmenleri lehine olması beklenirken diğer öğretmen adayları (sosyal bilgiler, sınıf, ilköğretim matematik, okul öncesi) lehine fark bulunmuştur. ${ }^{37}$ Yine Aksu, fen bilgisi ve sınıf öğretmenlerinin çevre sorunlarına yönelik tutumlarını belirlemek için yaptığı çalışma sonucunda öğretmenlerin çevre ve çevre sorunlarına karşı tutumlarının yüksek düzeyde olduğu ancak çevre tutum puanlarının ise cinsiyete, öğretmenlik deneyim süresine, branşa, çevre kuruluşuna üye olup olmama durumuna göre farklılık göstermediği sonucuna ulaşılmıştır. ${ }^{38}$ Çobanoğlu ve Türer, fen bilgisi ve sosyal bilgiler öğretmen adaylarının sürdürülebilir kalkınma farkındalıklarını belirlemek için yaptıkları çalışma sonucunda öğretmen

35 Karataş, Çevre Bilincinin, s.279.

36 Suat Polat, "Öğretmen Adaylarının (Sosyal Bilgiler, Fen Bilgisi, İlköğretim Din Kültürü Ve Ahlak Bilgisi, Türkçe) Çevre Sorunlarına Yönelik Tutumları”, Yüksek Lisans Tezi, Erciyes Üniversitesi, 2012, s.126.

37 Süleyman Ak, "İlköğretim Öğretmen Adaylarının Çevreye Yönelik Bilinçlerinin Bazı Demografik Değişkenler Açısından İncelenmesi”, Yüksek Lisans Tezi, Abant İzzet Baysal Üniversitesi, 2008, s.131.

38 Aksu, Fen ve Teknoloji, s.94. 
adaylarının okudukları bölüme göre aralarında anlamlı bir fark olmadığı sonucuna ulaşmışlardır. ${ }^{39}$

Öğretmen adaylarının cinsiyete göre aralarında anlamlı farklılık olup olmadığına bakılmış ve kız öğretmen adayları lehine anlamlı farklılık bulunmuştur. Kız öğrencilerin erkek öğrencilere göre yapıları itibariyle her zaman daha duyarlı ve hassas olmaları bu farkı oluşturmuş olabileceği düşünülmektedir. Bu sonuçla benzer sonuçlar bulan çalışmalar vardır. Ayeni, öğretmen adaylarının çevresel farkındalıklarını sosyo-demografik özellikler açısından incelemiş ve kız öğretmen adaylarının çevresel farkındalıklarını erkek öğretmen adaylarına göre daha anlamlı bulmuştur. ${ }^{40}$ Erol, s1nıf öğretmenliği ikinci sınıf öğrencilerinin çevre ve çevre sorunlarını incelemek için yaptığ 1 çalışmada kız öğrencilerin erkek öğrencilere göre çevre sorunlarına yönelik tutumlarının yüksek olduğu sonucuna ulaşılmıştır. ${ }^{41}$ Yapıcı, öğretmen adaylarının çevre sorunlarına yönelik farkındalık ve ilgi düzeylerini incelediği çalışmasında kız öğrencilerin çevre sorunlarına yönelik sorumluluk, farkındalık ve ilgi düzeylerinin daha yüksek ve önemli derecede farklı olduğu sonucuna ulaşmıştır. ${ }^{42}$

Polat, yaptığı çalışmada fen bilgisi öğretmen adaylarının çevre sorunlarına yönelik tutumları ile cinsiyetleri arasında fark bulmamıştır. ${ }^{43} \mathrm{Ak}$, yaptığı çalışmada öğretmen adaylarının cinsiyet ile çevre bilinci ölçeğinin bazı alt bölümleri arasında anlamlı farklılığın olduğu tespit edilmiştir. Bu anlamlı farklılık ise erkekler lehinedir. ${ }^{44}$ Aksakal, fen ve teknoloji öğretmen adaylarının çevresel geri dönüşüm konusundaki duyarlılıklarının belirlenmesi için yaptığı çalışmanın sonucunda öğretmen adaylarında cinsiyet faktörünün adayların çevresel geri dönüşüm konusundaki duyarlılıklarında anlamlı bir fark teşkil etmediği sonucuna ulaşmıştır. ${ }^{45}$

Araştırmada; fen bilgisi öğretmen adaylarının sınıf düzeylerine göre aralarına istatistiksel olarak anlamlı fark bulunmamıştır. Sınıf öğretmenliği bölümlerinde okuyan öğretmen adaylarının sınıf düzeylerine göre aralarında bir ve ikinci sınıflar arasında ve ikinci sınıflar ile dördüncü sınıflar arasında anlamlı fark bulunmuştur. Birinci sınıflar ile ikinci sınıflar arasındaki farklılığın 2. sınıfta çevre eğitimi dersinin olmasının etkilemiş olabileceği düşünülmüştür. İkinci sınıflar ile dördüncü sınıflar arasındaki farkın ise öğrenim süresi boyunca çevreye yönelik bilgi ve bilincin artmasının etkilemiş olabileceği düşünülmektedir. Fen bilgisi ve sınıf öğretmenliği bölümlerinin aynı sınıf düzeyleri birbiri ile karşılaştırıldığında birinci sınıfta okuyan öğretmen

39 Omca Çobanoğlu ve Berna Türer, "Fen Bilgisi ve Sosyal Bilgiler Öğretmenlerinin Sürdürülebilir Kalkınma Farkındalıklarının Belirlenmesi”, Uluslararası Türk Eğitim Bilimleri Dergisi, 2015: 235-247.

40 Olutoyosi O. Ayeni, "The influence of socio-demographic factors on environmental education. Awareness of first year students at the Cape Peninsula University of Technology South Africa", The international Journal of science in Society, 5 (2014): 1-8.

41 Gül Hanım Erol, "Sınıf Öğretmenliği İkinci Sınıf Öğrencilerinin Çevre ve Çevre Sorunlarına Yönelik Tutumları”, Yüksek Lisans Tezi, Pamukkale Üniversitesi, 2005, s.35.

42 Elvan Yapıcı, "Öğretmen Adaylarının Çevre Sorunlarına Yönelik Farkındalık ve İlgi Düzeylerinin Karşılaştırılması”, Yüksek Lisans Tezi. Adnan Menderes Üniversitesi, 2009, s.97.

43 Polat, Öğretmen Adaylarının, s.17.

44 Ak, İlköğretim Öğretmen, s.25.

45 Şeyma Aksakal, "Fen ve Teknoloji Dersi Öğretmen Adaylarının Çevresel Geri Dönüşüm Konusundaki Duyarlılıklarının Belirlenmesi”, Yüksek Lisans Tezi, Fırat Üniversitesi, 2013, s.78. 
adayları, ikinci sınıfta okuyan öğretmen adayları ve üçüncü sınıfta okuyan öğretmen adayları arasında anlamlı bir fark olmadığı sonucuna ulaşılmıştır. Dördüncü sınıf öğretmen adayları arasında ise fen bilgisi öğretmenliğinde okuyan öğretmen adaylarının lehine anlamlı fark olduğu sonucuna ulaşılmıştır.

Topaloğlu, yaptığı çalışmada fen bilgisi öğretmen adaylarının çevre sorunlarına yönelik tutumlarının kendi yaşam kalitelerine yansımalarının incelenmesi üzerine yaptığ larının sınıf düzeylerine göre farklılaşmadığı sonucuna ulaşmıştır. ${ }^{46}$ Öcal, sosyal bilgiler öğretmen adaylarının çevre sorunlarına yönelik tutumlarını incelediği çalışmada öğretmen adaylarının çevreye yönelik tutumlarında sınıf düzeylerine göre anlamlı farklılık olmadığı sonucuna ulaşmıştır. ${ }^{47}$ Gürbüz ve Çakmak, biyoloji eğitimi bölümü öğrencilerinin çevreye yönelik tutumlarının incelenmesi çalışmasında sınıf düzeylerine göre çevresel düşünce puanlarında 3. Sınıflar lehine anlamlı farklılık bulmuştur. ${ }^{48}$ Kocalar ve Balcı, coğrafya öğretmen adaylarının çevre okuryazarlık düzeylerini incelemek için yaptıkları çalışmada 4. ve 5. sınıflar lehine anlamlı farklılık bulmuştur. ${ }^{49}$ Sever ve Yalçınkaya, yaptıkları çalışmada sınıf öğretmenliği ikinci sınıf öğrencilerinin çevre bilincinin birinci sınıflara göre daha düşük olduğu sonucuna ulaşılmıştır. ${ }^{50}$ Akbaş, fen bilgisi öğretmen adaylarının çevre olgusunun araştırılması üzerine yaptığ çalışmada 4. Sınıf öğrencilerinin çevre ve kavram bilgilerinin 1 . sınıf öğrencilerine göre anlamlı fark gösterdikleri, çevre duyarlılıklarının da buna bağlı olarak daha fazla olduğu sonucuna ulaşmıştır. ${ }^{51}$

$\mathrm{Bu}$ araştırmada; öğretmen adaylarının anne eğitim düzeyi, baba eğitim düzeyi, mezun oldukları lise türü, ailelerinin gelir durumu ve yaşadıkları yerleşim yerinin türüne göre aralarında anlamlı fark bulunamamıştır. Türer, yaptığ 1 çalışmada fen bilgisi ve sosyal bilgiler öğretmenliği bölümlerinde okuyan öğretmen adaylarının sürdürülebilir çevreye yönelik tutumlarını incelemiş ve cinsiyete göre farklılık olmadığ sonucuna ulaşmıştır. ${ }^{52}$ Topaloğlu, fen bilgisi öğretmen adaylarının çevre sorunlarına yönelik tutumları üzerine yaptığı çalışma sonucunda çevre sorunlarının en uzun süre yaşadıkları yerleşim yerine göre farklılaşmadığı, baba eğitim durumuna göre farklılaşmadığı, hastalık olup olmama durumuna göre farklılaşmadığı sonucuna ulaşılmıştır. ${ }^{53}$ Altınöz, fen bilgisi öğretmen adaylarının çevre okuryazarlık düzeylerini incelemek için yaptığ na, anne babalarının eğitim durumlarına ve yaşadıkları yerleşim birimine göre çevre

46 Miray Topaloğlu, "Fen Bilgisi Öğretmen Adaylarının Çevre Sorunlarına Yönelik Tutumlarının Kendi Yaşam Kalitelerine Yansımalarının İncelenmesi”, Yüksek Lisans Tezi, Eskişehir Osmangazi Üniversitesi, 2014, s.117. 47 Tülay Öcal, "Sosyal bilgiler öğretmen adaylarının çevre sorunlarına yönelik tutumlarının belirlenmesi”, Marmara Dergisi, 27 (2013): 333-352.

48 Hasan Gürbüz ve Mürşet Çakmak, "Biyoloji bölümü öğrencilerinin çevreye yönelik tutumlarının incelenmesi”, Dicle Üniversitesi Ziya Gökalp Eğitim Fakültesi Dergisi, 19 (2012): 162-173.

49 Ali Osman Kocalar ve Ali Balcı, “Coğrafya Öğretmen Adaylarının Çevre Okuryazarlık Düzeyleri”, International Journal Social Science Research, 2/2 (2013): 15-49.

50 Ramazan Sever, Elvan Yalçınkaya, "Sınıf Öğretmeni Adaylarının Çevresel Tutumlarının İncelenmesi", Marmara Coğrafya Dergisi, 26 (2012): 1-15.

51 Akbaş, Fen Bilgisi, s.25.

52 Berna Türer, “Fen Bilgisi ve Sosyal Bilgiler Öğretmen Adaylarının Sürdürülebilir Kalkınma Farkındalıklarının Belirlenmesi”, Yüksek Lisans Tezi, Ondokuz Mayıs Üniversitesi, 2010, s.123

53 Topaloğlu, Fen Bilgisi, s.28. 
okuryazarlık bileşenleri arasında anlamlı bir fark olmadığı sonucuna ulaşmıştır. ${ }^{54}$ Karakoçan, yılında sınıf öğretmenlerinin çevre eğitimine yönelik farkındalıklarını belirlemek için yaptığı çalışmada öğretmenlerin çalıştıkları kurum, öğrenim durumları ve çalıştıkları yerleşim birimi açısından anlamlı bir farklılık olmadığı sonucuna ulaşılmıştır. ${ }^{55}$

Boz, fen bilgisi öğretmen adaylarının enerji kaynakları ve çevreye etkileri konusundaki bilgi düzeylerini incelemiştir ve aile eğitim seviyesi yüksek olanların, iyi liselerde eğitim görenlerin ve ortaöğretimde fen başarısı iyi olanların çevre konusunda bilgi düzeylerinin diğer adaylara göre daha yüksek olduğu sonucuna ulaşılmıştır. ${ }^{56}$ Polat, fen bilgisi, sosyal bilgiler, din kültürü ve ahlak bilgisi ve Türkçe öğretmen adaylarının çevre sorunlarına yönelik tutumlarını araştırdığı çalışma sonucunda ebeveyn eğitim düzeyi yüksek olan öğretmen adaylarının çevre sorunlarına yönelik tutumları arasinda ebeveynlerinin eğitim düzeyleri yüksek olanlar lehine anlamlı farklılık olduğu tespit edilmiştir. ${ }^{57}$ Bican, fen bilgisi öğretmen adaylarının çevre risk algılarını belirlemek için yaptığı çalışmada risk algılarının öğretim durumlarına mezun olunan lise türüne göre fark olduğunu tespit etmiştir. ${ }^{58}$ Polat, öğretmen adaylarının (sosyal bilgiler, fen bilgisi, ilköğretim din kültürü ve ahlak bilgisi, Türkçe) çevre sorunlarına yönelik tutumları üzerine yaptığ 1 çalışmada öğretmen adaylarının çevre sorunlarına yönelik tutumları ile ebeveynlerinin eğitim düzeyi arasında eğitim düzeyi yüksek ebeveynler lehine bir farklılık bulmuştur. ${ }^{59}$

\section{Öneriler}

Üniversite eğitim programlarının çevre eğitimi konusunda yeterli düzeyde olup olmadığı incelenmelidir.

Çevre dersleri sadece belli bir sınıfın belli bir döneminde alınan bir ders olmaktan çıkarılıp tüm disiplinlerle ilişkilendirilmelidir.

Çevre eğitimi derslerinde öğrenilen bilgileri gündelik yaşantıya entegre edecek şekilde etkinlikler düzenlenmelidir.

Öğretmen adaylarının sürdürülebilir çevreye yönelik tutumlarının daha yüksek olması için üniversitelerde sık sık seminer ve konferanslar düzenlenmelidir.

Öğrencilerin sürdürülebilirliğin önemini kavramaları ve çevrelerine de bu bilinci kazandırmaları için üniversitelerde kulüpler, gönüllü kuruluşlar açılması ve öğrencilerin bu kulüp ve kuruluşlara katılması teşvik edilmelidir.

54 Nihat Altınöz, “Fen Bilgisi Öğretmen Adaylarının Çevre Okuryazarlık Düzeyleri”, Yüksek Lisans Tezi, Sakarya Üniversitesi, 2010, s.83.

55 Esra Karakoçan, "Sınıf Öğretmenlerinin Çevre Eğitimine Yönelik Farkındalıkları”, Yüksek Lisans Tezi. Afyon Kocatepe Üniversitesi, 2016, s.104.

56 Can Sercan Boz, "Eğitim Fakültesi Fen Bilgisi Öğretmen Adaylarının 'Enerji Kaynakları ve Çevreye Etkileri’ konusundaki bilgi düzeylerinin araştırılması”, Yüksek Lisans Tezi, Kastamonu Üniversitesi, 2014, s.90.

57 Polat, Öğretmen Adaylarının, s.32.

58 Simge Bican, "Fen Bilgisi Öğretmen Adaylarının Çevre Risk Algılarının Belirlenmesi”, Yüksek Lisans Tezi, Gazi Üniversitesi, 2014, s.101.

59 Polat, Öğretmen Adaylarının, s.112. 
Sürdürülebilirliğin sadece bir alanda eğitim gören adayların bilmesi ve uygulaması gereken bir konu olarak görülmemesi için tüm bölümlerde ve tüm derslerde sürdürülebilirlik bilincini kazandıracak şekilde düzenlemeler yapılmalıdır.

\section{Kaynakça}

Ak, Süleyman. "İlköğretim Öğretmen Adaylarının Çevreye Yönelik Bilinçlerinin Bazı Demografik Değişkenler Açısından İncelenmesi”. Yüksek Lisans Tezi, Abant İzzet Baysal Üniversitesi, 2008.

Akbaş, Tuğba. "Fen Bilgisi Öğretmen Adaylarında Çevre Olgusunun Araştırılması”. Yüksek Lisans Tezi, Atatürk Üniversitesi, 2007.

Akgül, Hasan Celal ve Esra Macaroğlu Akgül. "Fen Eğitiminde Yeni Bir Kavram: Tarımsal Farkındalık İlköğretim Öğretmen Adaylarının Genel, Fen Bilgisi Öğretmen Adaylarının Özel Durumu”. Sakarya Üniversitesi Eğitim Dergisi. 1/1 (2010): 15-25.

Akıllı, Mustafa ve Mustafa T. Yurtcan. "İlköğretim fen bilgisi öğretmeni adaylarının çevreye karşı tutumlarının farklı değişkenler açısından incelenmesi (Kazım Karabekir Eğitim Fakültesi Örneği)”. Erzincan Eğitim Fakültesi Dergisi. 11/2 (2009): 119-131.

Aksakal, Şeyma. "Fen ve Teknoloji Dersi Öğretmen Adaylarının Çevresel Geri Dönüşüm Konusundaki Duyarlılıklarının Belirlenmesi”. Yüksek Lisans Tezi. Firat Üniversitesi, 2013.

Aksu, Yasemin. "Fen ve Teknoloji ile Sınıf Öğretmenlerinin Çevre Sorunlarına Yönelik Tutumlarının Belirlenmesi (Burdur İli Örneği)”. Yüksek Lisans Tezi, Süleyman Demirel Üniversitesi, 2009.

Akyol, Buket. "İlköğretim Öğretmen Adaylarının Çevresel Tutum ve Çevre Bilgi Düzeyleri Üzerine Bir Çalışma”. Yüksek Lisans Tezi, Niğde Üniversitesi, 2014.

Alpak, Gizem. "Fen Bilgisi Öğretmen Adaylarının Çevreye Yönelik Etik Yaklaşımları İle Sürdürülebilir Çevreye Yönelik Tutumlarının İncelenmesi”. Yüksek Lisans Tezi, Adnan Menderes Üniversitesi, 2016.

Altınöz, Nihat. "Fen Bilgisi Öğretmen Adaylarının Çevre Okuryazarlık Düzeyleri”. Yüksek Lisans Tezi, Sakarya Üniversitesi. 2010.

Atasoy, Emin ve Hasan Ertürk. "İlköğretim Öğrencilerinin Çevresel Tutum ve Çevre Bilgisi Üzerine Bir Alan Araştırması”. Erzincan Eğitim Fakültesi Dergisi. 10/1 (2008): 105-122.

Ayeni, Olutoyosi O. "The influence of socio-demographic factors on environmental education. Awareness of first year students at the Cape Peninsula University of Technology South Africa". The international Journal of science in Society. 5 (2014): 1-8.

Bican, Simge. "Fen Bilgisi Öğretmen Adaylarının Çevre Risk Algılarının Belirlenmesi”. Yüksek Lisans Tezi. Gazi Üniversitesi, 2014, s.101.

Bilim, İrfan. "Sürdürülebilir Çevre Açısından Eğitim Fakültesi Öğrencilerinin Çevre Okuryazarlık Düzeylerinin Belirlenmesi”. Yüksek Lisans Tezi, Afyon Kocatepe Üniversitesi, 2012. 
Büyüköztürk, Şener, Ebru Kılıç Çakmak, Özcan Erkan Akgün, Şirin Karadeniz ve Funda Demirel. “Bilimsel Araştırma Yöntemleri”. Ankara: Pegem Yayınları. 2012.

Çelikbaş, Ayşe. "Sürdürülebilirliği Temel Alan Çevre Eğitiminin Ortaokul Öğrencilerinin Çevresel Davranışlarına ve Sürdürülebilir Çevre Tutumlarına Etkisi”. Yüksek Lisans Tezi, Mersin Üniversitesi, 2016.

Çimen, Osman. "Çevre Eğitiminde Tatlı Su Ekosistemleri Konusundaki Temel Kavramların Üniversite Öğrencileri Tarafından Algılanma Düzeyleri”. Yüksek Lisans Tezi, Gazi Üniversitesi, 2008.

Çobanoğlu, Omca ve Berna Türer. "Fen Bilgisi ve Sosyal Bilgiler Öğretmenlerinin Sürdürülebilir Kalkınma Farkındalıklarının Belirlenmesi”. Uluslararası Türk Eğitim Bilimleri Dergisi. (2015): 235-247.

Erten, Sinan. "Çevre Eğitimi ve Çevre Bilinci Nedir, Çevre Eğitimi Nasıl Olmalıdır?”. Çevre ve İnsan Dergisi. 65/66 (2004): 1-13.

Gadenne, David L., Jessica Kennedy, Catherine McKeiver. "An empirical study of environmental awareness and practices in SMEs". Journal of Business Ethics. 84 (2009): 45-63.

Gürbüz, Hasan ve Mürşet Çakmak. "Biyoloji bölümü öğrencilerinin çevreye yönelik tutumlarının incelenmesi”. Dicle Üniversitesi Ziya Gökalp Eğitim Fakültesi Dergisi. 19 (2012): 162-173.

Hanım Erol, Gül. "Sınıf Öğretmenliği İkinci Sınıf Öğrencilerinin Çevre Ve Çevre Sorunlarına Yönelik Tutumları”. Yüksek Lisans Tezi, Pamukkale Üniversitesi, 2005 .

Kahraman, Nazan. "Eğitim Fakültesi Öğrencilerinin Çevre Sorunlarına Yönelik Normlarının Karşılaştırılması”. Yüksek Lisans Tezi, Adnan Menderes Üniversitesi, 2016.

Kahyaoğlu, Mustafa ve Nurettin Özgen. “Öğretmen Adaylarının Çevre Sorunlarına Yönelik Tutumlarının Çeşitli Değişkenler Açısından İncelenmesi”. Kuramsal Eğitimbilim Dergisi. 5/2 (2012): 171-185.

Karakoçan, Esra. "Sınıf Öğretmenlerinin Çevre Eğitimine Yönelik Farkındalıkları”. Yüksek Lisans Tezi, Afyon Kocatepe Üniversitesi, 2016, s.104.

Karataş, Abdullah. "Çevre Bilincinin Geliştirilmesinde Çevre Eğitiminin Rolü ve Niğde Üniversitesi Eğitim Fakültesi Örneği”. Doktora Tezi, Ankara Üniversitesi, 2013.

Kocalar, Ali Osman ve Ali Balcı. “Coğrafya Öğretmen Adaylarının Çevre Okuryazarlık Düzeyleri”. International Journal Social Science Research. 2/2 (2013): 15-49.

Öcal, Tülay. "Sosyal bilgiler öğretmen adaylarının çevre sorunlarına yönelik tutumlarının belirlenmesi”. Marmara Dergisi. 27 (2013): 333-352.

Özcan, Seher. "Fen Bilgisi Öğretmen Adaylarının Çevre Sorunlarına İlişkin Görüşlerinin Farklı Teknikler Kullanılarak Tespit Edilmesi”. Yüksek Lisans Tezi, Abant İzzet Baysal Üniversitesi, 2010. 
Özdemir, Oğuz. Ekolojik Okuryazarlık ve Çevre Eğitimi. Ankara, Pegem Akademi, 2016.

Polat, Suat. "Öğretmen Adaylarının (Sosyal Bilgiler, Fen Bilgisi, İlköğretim Din Kültürü ve Ahlak Bilgisi, Türkçe) Çevre Sorunlarına Yönelik Tutumları”. Yüksek Lisans Tezi, Erciyes Üniversitesi, 2012.

Sercan Boz, Can. "Eğitim Fakültesi Fen Bilgisi Öğretmen Adaylarının 'Enerji Kaynakları ve Çevreye Etkileri’ Konusundaki Bilgi Düzeylerinin Araştırılması”. Yüksek Lisans Tezi, Kastamonu Üniversitesi, 2014.

Sever, Ramazan ve Elvan Yalçınkaya. "Sınıf Öğretmeni Adaylarının Çevresel Tutumlarının İncelenmesi”. Marmara Coğrafya Dergisi. 26 (2012): 1-15.

Soysal, Kübra. "İlköğretim Öğretmen Adaylarının Sürdürülebilir Çevre Eğitimine Yönelik Tutumları”. Yüksek Lisans Tezi, Ondokuz Mayıs Üniversitesi, 2016.

Strong, Carolyn. "The impact of environmental education on children's knowledge and awareness of environmental concerns". Marketing Intelligence \& Planning. 16 (1998): 349-355.

Teksöz, Gaye, Elvan Şahin ve Hamide Ertepınar. "Çevre okuryazarlığı, öğretmen adayları ve sürdürülebilir bir gelecek”. Hacettepe Üniversitesi Eğitim Fakültesi Dergisi. 39 (2010): 307-320.

Topaloğlu, Miray. “Fen Bilgisi Öğretmen Adaylarının Çevre Sorunlarına Yönelik Tutumlarının Kendi Yaşam Kalitelerine Yansımalarının İncelenmesi”. Yüksek Lisans Tezi, Eskişehir Osmangazi Üniversitesi, 2014.

Tuncer, Gaye, Ceren Tekkaya ve Semra Sungur. "Öğretmen Adaylarının Sürdürülebilir Kalkınma ile ilgili inançları Cinsiyet ve Çevre Dersine Katılımın Etkisi”. Hacettepe Üniversitesi Eğitim Fakültesi Dergisi. 31 (2006): 179-187.

Türer, Berna. "Fen Bilgisi ve Sosyal Bilgiler Öğretmen Adaylarının Sürdürülebilir Kalkınma Farkındalıklarının Belirlenmesi”. Yüksek Lisans Tezi, Ondokuz Mayıs Üniversitesi, 2010.

Uğulu, İlker ve Sevilay Erkol. "Biyoloji öğretmen adaylarının çevreye yönelik tutumları ve çeşitli değişkenler açısından incelenmesi”. Balıkesir Üniversitesi Yeni Dünya Bilimleri Akademisi e-Dergisi.8/1 (2013): 78-89.

Yapıcı, Elvan. "Öğretmen Adaylarının Çevre Sorunlarına Yönelik Farkındalık ve İlgi Düzeylerinin Karşılaştırılması”. Yüksek Lisans Tezi, Adnan Menderes Üniversitesi, 2009.

Yıldız, Şahika. "Öğretmenlerin, Öğretmen Adaylarının ve Öğrencilerin Sürdürülebilir Çevre ile İlgili Kavramsal Anlamaları ve Tutumları”. Yüksek Lisans Tezi, Dokuz Eylül Üniversitesi, 2011.

Yücel, A. Seda ve F. İnci Morgil. "Yüksek Öğretimde Çevre Olgusunun Araştırılması". Hacettepe Üniversitesi Eğitim Fakültesi Dergisi. 14 (1998): 84-91. 
İNSAN\&İNSAN, Y11/Year 6, Say1/Issue 21, Yaz/Summer 2019, 525-542

DOI: https://doi.org/10.29224/insanveinsan.475471

\title{
The Investigation of Science and Classroom Teacher Candidates Attitudes to Sustainable Environment
}

\author{
HICRET ÇIMEN / SEMRA BENZER
}

\begin{abstract}
The aim of this study was to investigate the attitudes of prospective teachers studying in science and classroom teaching departments towards sustainable environment. The research was carried out with 342 science teachers and 324 classroom teacher candidates who were studying in Gazi University Faculty of Education during the 2017-2018 academic year. Screening model was used in the research. Personal information form and Sustainable Environment Attitude Scale were used to obtain data. According to the findings obtained from the research, prospective teachers' attitudes towards sustainable environment were found to be high. There is a significant difference in favor of prospective teachers in science teaching departments and in favor of female teacher candidates according to gender. There was no difference between the grade levels of science teacher candidates. A significant difference was found between the 1-2 and 2-4 classes of classroom teaching class levels.
\end{abstract}

Keywords: Success, Teacher candidates, Sustainable environment, Attitude. 